\title{
Um paladino da monarquia na imprensa republicana
}

\author{
Antonio Arnoni Prado
}

\author{
Perdida é para mim toda a esperança \\ De volver ao Brasil; de lá me veio \\ Um pugilo de terra: e nesta, creio, \\ Brando será meu sono sem tardança...
}

D. Pedro de Alcântara

O jornal L'Independence Belge, de Bruxelas, informava a 2 de fevereiro de 1913 a chegada do novo ministro do Brasil na Bélgica, Gastão da Cunha, em substituição ao embaixador Oliveira Lima, que a notícia definia como um diplomata brilhante "que soube defender com patriotismo os interesses de seu país". "A partida desse eminente diplomata ainda jovem - sublinha o jornal - será bastante sentida na Bélgica". E acrescenta, referindo-se ao destino do ex-ministro plenipotenciário que se retirava, que ele se encontrava "atualmente em viagem de conferências pelos Estados Unidos.

Sobre as razões que levaram Oliveira Lima a deixar o cargo havia apenas uma carta publicada no Estado de S. Paulo de 12 de setembro de 1912 em que o ex-ministro explicava a um amigo que decidira pedir a sua aposentadoria "devido aos desgostos que lhe causaram alguns atos do ministério do Exterior". Aludia, com isso, ao convulso panorama político brasileiro dos últimos meses de 1912, quando a velha questão da restauração monárquica voltava a agitar o ambiente institucional da República. Na verdade, a questão de seus vínculos com a monarquia vinha desde os avanços da campanha civilista, em 1909-1910, quando Oliveira Lima se alinhou entre os maiores entusiastas da candidatura de Rui Barbosa à Presidência da República no pleito contra Hermes da Fonseca.

Ainda na Bélgica, na Exposição de 1910 em Bruxelas, conheceu o príncipe D. Luiz de Orléans e Bragança, filho da princesa Isabel, que desde 1907 tentava articular com as bases do Diretório Monarquista do Rio de Janeiro uma ação conjunta que o levasse ao poder, ao qual era o primeiro aspirante desde a renúncia de seu irmão Pedro. Sobre o príncipe, que havia lançado em abril de 1909, pelo jornal O Estado de S. Paulo, uma ruidosa carta-manifesto que repercutiu no contexto das idéias civilistas então em marcha, Oliveira Lima publica em 1910, primeiro em Paris e depois em São Paulo, o artigo "Um príncipe brasileiro no pavilhão do Brasil em Bruxelas", no qual não apenas exalta o regime imperial, como também a figura magnânima de Pedro II. ${ }^{1}$

No ano seguinte, pronuncia na Sorbonne uma série de conferências depois recolhidas no volume Formation historique de la nationalité bresiliènne, nas quais, além de reafirmar o caráter próspero e integrador do regime monárquico, celebra a grandeza do Imperador e a excelência de seu caráter. À publicação desse artigo, seguiu-se a coordenação de uma campanha, iniciada pelo próprio Oliveira Lima, com vistas a revogar o banimento 
da família imperial, que segundo ele se "constituía numa iniqüidade histórica inaceitável". ${ }^{2}$

É com esse espírito - estigmatizado pelos republicanos e repudiado pelos militares - que Oliveira Lima deixou a Bélgica em fins de 1912 para retornar ao país então sobressaltado pela chamada questão da restauração monárquica. ${ }^{3}$ Em dezembro desse ano, com efeito, a Gazeta de Notícias, preocupada com o rumo dos acontecimentos, iniciava uma série de entrevistas com vários monarquistas ilustres, "para saber o que eles pensavam da possibilidade de uma mudança de regime”. João Alfredo, sempre tão cordial, foi incisivo: "Não respondo a essas perguntas. Peço não insista". Carlos de Laet esquivou-se asperamente no saguão do Jornal do Brasil: "Estou doente. Poupe-me a sua pergunta". Afonso Celso respondeu, mas por carta. Disse que a resposta, por envolver questões de grande responsabilidade, "não devia ser dada de afogadilho", principalmente agora que vivia "de todo alheio às agitações políticas", dirigindo uma escola de leis e colaborando quase que diariamente no Jornal do Brasil, onde escrevia sobre temas religiosos e sociais. Mesmo assim, não se recusou a dar a sua opinião pessoal. "Permaneço inabalavelmente fiel à bandeira que abracei em 15 de novembro de 1889: os fatos, longe de enfraquecer, têm corroborado a minha convicção de que o regime atual não é o apropriado às tradições e destinos do Brasill”.

No dia 9 de dezembro de 1912 o jornal O País noticiava o desembarque de Oliveira Lima e sua esposa, dona Flora, no cais Pharoux, procedentes do Velho Mundo. Depois de aludir ao êxito das conferências que o ex-ministro proferira em Paris, Bruxelas e Nova Iorque e que segundo a nota demonstravam "O grande amor que ele votava à sua Pátria", diz o jornal que Oliveira Lima era "um verdadeiro embaixador do Brasil, não apenas perante um governo ou uma corte, mas perante a civilização ocidental". Sua presença no país nesse momento de graves atribulações políticas reacendia - segundo a nota - o compromisso com a missão histórica que s. exa. não poderia deixar de cumprir como "um cuidadoso cultor do passado procurando, como todos nós, consolar-se talvez das agruras do presente, com a contemplação da grandeza iniludível da nossa historia". Por ser ele um "apaixonado observador de quanto de nobre possuímos no nosso passado" - acrescenta o jornal que Oliveira Lima podia ser considerado como um soldado da restauração, não apenas porque conhecia de perto a força e a energia da nossa raça, mas também porque sabia que um povo, "quando tem uma história feita de glórias nobremente conquistadas, não pode deixar de cumprir a missão histórica que o destino lhe reservou".

A Gą̧eta de Notícias deu em destaque a presença de diversos amigos que foram receber o casal a bordo do paquete Vazari, entre eles o barão Homem de Melo, o poeta Augusto de Lima, o ministro Barros Moreira, o crítico José Veríssimo, além de Sílvio Romero filho que, representando o ministro Lauro Muller, levou flores a dona Flora, momentos antes de a comitiva seguir para o Hotel dos Estrangeiros, onde o casal costumava se hospedar. Na saída, indagado pelos repórteres, Oliveira Lima afirmou não saber ao certo qual a sua verdadeira condição de momento, "se a de ministro aposentado ou em disponibilidade". Tinha apenas certeza de que, depois do Rio de Janeiro, seguiria para São Paulo e em seguida para Pernambuco, onde pretendia descansar. Pouco antes de se retirar, ainda pediu notícias de Rui Barbosa, de cujo último discurso sobre o Governo Provisório acabara de tomar conhecimento. 
No dia seguinte o Correio da Manhã informava que, em entrevista concedida no Hotel dos Estrangeiros, Oliveira Lima havia confirmado a sua decisão de aposentar-se. Estava cansado da dura batalha que vinha travando para reunir os seus livros - "cerca de 16 mil volumes, mais de 8 mil dos quais sobre o Brasil" - em sua maioria espalhados por Lisboa, Paris, Londres e Bruxelas. Quanto à possibilidade de ingressar na política, não fechava de todo as portas. "Com 45 anos tudo é possível", admitiu ao repórter.

$\mathrm{Na}$ Gazeta de Notícias, porém, a questão do ingresso na vida política vinha num tom diferente. Aparentemente mais comedido, Oliveira Lima declara ao jornal que a decisão não era para logo. Não entraria de pronto na vida partidária devido aos compromissos de ordem intelectual, entre eles o de preparar o volume Brasil: 20. Império para "a grande História da América que foi projetada em Paris por ilustres pensadores", além de outros trabalhos por concluir. Mas perguntado pelo repórter sobre se era monarquista, surpreende a todos com uma resposta inesperada: "E quem o não é, hoje, no Brasil?". "Dos que sabem pensar, raros são ainda os que se mantêm no romantismo de uma preferência republicana", arremata, pondo fogo na conversa.

O repórter, animado, aceita a provocação e pede a opinião do ex-ministro sobre D. Luiz de Orléans e Bragança, neto de D. Pedro e pretendente direto à Coroa do Brasil. "No caso de uma restauração, acredita que ele estaria em condições de dirigir os destinos do país? - é a pergunta. Oliveira Lima vai direto ao ponto e diz não ter a menor dúvida de que D. Luiz estava à altura dessa missão, por ser "um admirável tipo de príncipe moderno, capaz de assumir a direção de um grande povo, por mais exigente que ele seja nos seus sentimentos liberais". Para surpresa do jornalista, acrescenta que esteve há poucos dias com o príncipe em Paris e que intercedeu para que suas obras fossem publicadas no Brasil. "D. Luiz é um convicto da restauração que entende, sinceramente, que a repetição histórica, com a monarquia, é a salvação da pátria”. E antes que o repórter se antecipasse, mostrou que sabia do que estava falando, ao enumerar alguns pontos do que seria o programa de seu futuro governo monarquista, entre eles a manutenção da federação, o respeito à autonomia dos estados e a valorização do Exército, "por ser ele um soldado e por não admitir a associação harmônica entre o socialismo e a monarquia", concluiu.

Não tarda e surgem n'O País do dia 12 os primeiros boatos de que o dr. Oliveira Lima ia assumir a direção do partido monarquista. Que os brasileiros evitassem, no entanto, "lançar mãos de meios extremos" para não provocar a ira do governo, advertia o jornal. "Há de vir um dia - acrescentava a nota - em que a palavra de ordem não partirá mais dos palácios de governo, mas da opinião pública", confirmando a convicção de um dos nossos mais notáveis intelectuais de que "a restauração monárquica era indispensável ao Brasil”.

"Utopia de hoje, realidade de amanhã", eis a chamada do jornal $A$ Época desse mesmo dia 12, que estampava um artigo de Vicente Toledo de Ouro Preto, filho do venerável Visconde, saudando o retorno do emérito patrício Oliveira Lima, que chegava da Europa "monarquista e convicto partidário do sr. D. Luiz de Bragança, o Príncipe Imperial Brasileiro". "Oxalá que assim seja", ele acrescenta, porque assim será possível mostrar ao povo brasileiro que a monarquia proporciona mais igualdade de direitos que a 
república e que, nela, todo cidadão pode aspirar a um cargo de comando no país, como mostrou a experiência de "67 anos de ordem, liberdade e grandeza". Para Toledo de Ouro Preto, Oliveira Lima está mais do que correto quando sustenta que "a solução está em D. Luiz de Bragança, o político, o escritor, o viajante, o militar que serviu na paz e na guerra, aquele que recebeu com o sangue a decisão, a energia de D. Pedro I, o fundador da nacionalidade, e a faculdade do trabalho inteligente e de estudo de D. Pedro II, o Magnânimo".

Com a mesma veemência manifestam-se no campo oposto as primeiras vozes em favor do regime. Um editorial de $A$ Notícia sustenta nessa mesma tarde que a República, ao contrário do que se vinha propalando, "não destruiu as esperanças de uma renovação das energias nacionais" que, assegurava, continuavam muito vivas do coração do povo brasileiro", não obstante os descaminhos da solução militar. "Os próprios militares, envergonhados do insucesso", assevera o jornal que saberiam reconhecer os imperativos da ordem civil que haveriam de levar a caserna "a acompanhar o povo na obra de reconstrução da nova ordem e do novo progresso".

A Gazeta da Tarde, num tom mais alarmante, chama atenção para a gravidade dos fatos que se desenrolavam no país. Para o jornal, as declarações de Oliveira Lima em favor da monarquia constituíam uma verdadeira ameaça à ordem institucional e por isso resolve indagar do ministro Lauro Muller, chefe do Itamaraty e responsável pelo futuro do ex-ministro àquela altura sem cargo, se s. exa. "estava acompanhando o movimento do sr. Oliveira Lima com relação às instituições republicanas”. $\mathrm{Na}$ opinião do jornal, "esse diplomata - como é dito com todas as letras nos termos da entrevista - "está ameaçando o regime republicano". Como circulassem pela imprensa rumores de que o chanceler nomearia o sr. Oliveira Lima para ministro do Brasil em Londres, a questão que se punha para a Gazeta era a de saber se Lauro Muller, "após tudo isso, o manteria na representação do Brasil no estrangeiro". O fato é que a divulgação desse libelo secundava outra nota alarmante do Correio da Noite afirmando nessa mesma tarde que o "encarregado de fazer a propaganda da República no exterior" (leia-se Oliveira Lima), o que fazia na verdade era "fomentar a anarquia interna do país e lá, à distância, pactuar com os seus maiores inimigos". Para o Correio a indiferença do ministro Lauro Muller, além de grave, "era um crime contra a família republicana, um conluio quase" ante o procedimento criminoso do ex-ministro, que segundo o jornal chefiava "às escâncaras um movimento demolidor das instituições a que ele jurou servir com lealdade". ${ }^{4}$

Na maré montante desse alvoroço, em 18 de dezembro de 1912 um observador político do jornal $A$ Noite garantia existir no Brasil, "uma propaganda restauradora que se vai tornando intensa" e cuja escalada já preocupava as autoridades. Pior é que os dados de que dispunha não se circunscreviam apenas ao Rio de Janeiro. "Em São Paulo os monarquistas invadiam todos os meios de comunicação e programavam uma série de conferências; no norte a campanha se alastrava: em Manaus acabava de fundar-se um clube monarquista com grande número de sócios e sucursais em outros Estados. Falavase num jornal em Belém ou Manaus. Em Manaus circulavam cartões postais com o retrato e o fac-simile da assinatura de D. Luiz de Orléans e Bragança”. 
Acuado pelos rumores que se intensificavam, Oliveira Lima se apressa em atenuar o impacto de suas declarações. Pouco antes, num discurso que $O$ Imparcial de 13 de dezembro publicara com o título de "O civilismo é o meu crédito político", já falava em termos conciliadores. "Não sou, declaradamente, monarquista - ele explica. O que afirmei é que a forma de governo monárquico é superior à republicana, porque acaba com as agitações, tão reprováveis, ainda que explicáveis, das eternas, constantes e seguidas sucessões presidenciais". Para o público, queria deixar uma outra mensagem: "não vim ao Brasil, absolutamente, bater-me pela restauração da monarquia, nem declarar-me monárquico, principalmente agora que ainda sou funcionário público".

A explicação não surtiu os efeitos esperados e as coisas tomam o rumo do estardalhaço. A Gažeta da Tarde, já identificava Oliveira Lima ao sebastianismo dos ressentidos que retornavam agora para se contrapor aos avanços sociais e políticos do Brasil republicano e soberano. E propalava que a campanha sebastianista estava nas ruas de novo, agora escorada num livro programático do príncipe D. Luiz de Orléans e Bragança ${ }^{5}$ e na pregação doutrinária de um diplomata que não tinha absolutamente o direito de afrontar as instituições por ser um funcionário da Nação. Inconformado, Francisco Glicério, o general republicano, vem a público pela Gazeta de Notícias desse mesmo dia 13 para desmentir que estivesse apoiando a plataforma monarquista e o projeto restaurador atribuído a Oliveira Lima. Dizia-se "um velho soldado republicano que ainda não descansou desde 3 de dezembro de 1870 à época em que fundamos o memorável partido que em 19 anos de lutas teve a ventura suprema de fundar, organizar e consolidar na essência o novo regime".

"D. Luiz surge definitivamente na política nacional?" - insiste a mesma Gazeta de Notícias de 14 de dezembro ao entrevistar um dos chefes da trincheira oposta, o conde de Afonso Celso, desencantado as loucuras e os desmandos da República, que segundo ele abalavam o bem-estar e o respeito à liberdade "outorgada outrora à vida da nação pelo monarca”. Por isso - ao contrário de Francisco Glicério - julga que atitude de Oliveira Lima era uma prova cabal de que a monarquia era uma coisa viável no Brasil. E Afonso Celso fala em instalação da monarquia "com todas as belas qualidades decorrentes dos proventos da civilização hodierna", com o rei assumindo a suprema magistratura do país com a função de julgar em última instância. "Carecemos de um rei, nada mais", acrescenta.

Diante dos rumores insistentes de que o ministro Lauro Muller, do Exterior, cogitava da indicação Oliveira Lima para embaixador do Brasil nos Estados Unidos, a Gaz̧eta do dia 16 volta à carga e acusa o ministro de premiar com esse posto a um homem "que teve a franqueza criminosa de declarar que estamos sob o domínio de um regime falido". Na manhã seguinte vem a resposta de O País, assegurando que Oliveira Lima não seria aposentado, dados os indícios (colhidos de boa fonte) de que o ex-ministro seria enviado para Londres ou Washington, indo Domício da Gama para uma subsecretaria de Estado e Régis de Oliveira para a chancelaria de Buenos Aires. O próprio Lauro Muller, segundo a nota, "fez ver ao nosso distinto patrício que a diplomacia não podia, por enquanto, dispensar o concurso precioso da sua competência e do seu patriotismo".

A Época desse mesmo dia 17 de dezembro amplia defesa ao transcrever trecho de uma carta de Fradique Mendes sob o título chamativo de "A restauração monárquica no Brasil - uma profecia de Eça de Queirós", com a clara finalidade de exaltar os ideais da 
restauração. "Receio que o Brasil tem ainda uma chance de reentrar numa vida nacional e só brasileira" - eis por onde começava o trecho escolhido pela redação para atualizar a mensagem de Fradique e assim chegar ao ponto que lhe interessava: "Quando por seu turno essa república jacobino-positivista murchar como planta colocada artificialmente sobre o solo e sem raízes nele e desaparecer de todo, uma manhã, levada pelo vento europeu e doutoral que a trouxe; e quando de novo sem luta e por uma mera conclusão lógica surgir no Paço de São Cristóvão um novo Imperador ou Rei - o Brasil, repito, nesse momento, tem uma chance de desembarcar do tapete europeu que o recobre, o desfeiteia e sufoca". E completa: "A chance está em que o novo Imperador ou Rei seja um moço forte, são, de bom parecer, bom brasileiro, que ame a natureza e deteste o livro [...] mais vale ser um lavrador original do que um doutor mal traduzido do francês".

A divulgação da carta coincide com o depoimento de Carlos de Laet que, a exemplo de Afonso Celso, decide responder ao inquérito da Gazeta de Notícias "D. Luiz surge definitivamente na política nacional?", em entrevista que sai publicada no dia 18 de dezembro de 1912. A princípio, ele acha precipitado "passarem diploma de militante monarquista" ao sr. Oliveira Lima, justamente por ser algo que poderá prejudicá-lo "neste regime intolerante com os que dele divergem". Mas se declara simpático ao nome do ex-ministro e diz acreditar na sua cruzada política, por entender que a República já não contava sequer consigo mesma, tanto a assustavam "manifestações meramente teóricas" e destituídas de qualquer sustentação armada. "O assombro, se não pavor, do sr. Glicério, no Senado - afirma Laet - demonstra a última parte do meu asserto". Para ele, Oliveira Lima, ao contrário, por exemplo, de Joaquim Nabuco, cujo monarquismo a seu ver "atrofiouse no mundo oficial e diplomático", trouxe uma nova luz premonitória a confirmar que "a Providência nos devia a nós, os monarquistas, essa compensação do triunfo monárquico na brilhante mentalidade de outro diplomata". Suas palavras finais, a exemplo do que ocorreu com o conde de Afonso Celso, valem como uma profissão de fé no credo monárquico. "Nas condições de minha pátria - ele escreve - o que mais lhe convém é a monarquia, com as garantias e restrições que nos assegurem as liberdades cívicas de que ora estamos privados". Mesmo considerando duro "ter de ir buscar alguém no estrangeiro, Laet tece elogios à figura do príncipe D.Luiz, vendo nele "o soldado, o escritor, o neto de D. Pedro II, o Magnânimo, e filho de Isabel, a redentora". Conclui afirmando que "nenhum militar se oporia pela força à realização de uma reforma de que depende a integridade militar". Sem a restauração - que lamenta estar velho para alcançar em vida - o país a seu ver acabaria fatalmente desmembrado.

Em 20 de dezembro, compelida pela velocidade dos fatos, a Gazeta de Notícias dá destaque ao próprio Manifesto de D. Luiz, segundo o jornal redigido "quando Sua Alteza se recomendou ao Diretório Monarquista na qualidade de pretendente ao trono do Brasil". E enumera os principais objetivos de seu programa de governo, entre os quais o de manter a federação, não em sua autonomia plena, mas no desenvolvimento integrado de cada estado; o de constituir um Exército e uma Marinha proporcionais à população de nosso vasto território; o de introduzir a instrução livre, mas não obrigatória, bem como o de garantir a instituição da justiça unitária e independente. O governo monarquista de D. Luiz daria todo respaldo às ações individuais, limitando-se o Estado a regularizar a atividade econômica e a fomentar a aliança entre o capital e o trabalho, assegurada pela 
modernização do país. Outros desígnios eram o de separar a Igreja do Estado, regulamentando as novas relações do Brasil com a Santa Sé; garantir o ensino religioso nas escolas; re-estabelecer o Conselho de Estado e as ordens honorificas e recompensar os serviços públicos relevantes, assim como "as virtudes exemplares de certas famílias".

A Época de 21 de dezembro alarga a divulgação das "Idéias de D. Luiz de Bragança", anexando uma "Carta de D. Isabel", datada de 9 de novembro de 1908, dirigida aos membros do Diretório monárquico, na qual a soberana agradecia os cumprimentos recebidos por ocasião do casamento de seu filho Luiz, que teve lugar em Cannes no dia 4 desse mesmo mês, e anunciava o casamento de seu outro filho, D. Pedro de Alcântara, a ser celebrado no dia 14 de novembro. No mesmo documento, a Princesa informava que D. Pedro assinara sua renúncia ao trono do Brasil no dia 30 de outubro de 1908, cujo facsímile vinha estampado em anexo.

Tão tensos corriam esses dias que o parlamento, em debates acalorados e cheios de conflitos, decidiu interromper a escalada política do príncipe D. Luiz de Orléans e Bragança não revogando o banimento da família imperial, que assim ficava impedida de retornar do exílio. "Não foi revogado o banimento da Família Imperial - O exílio continua - Discursos acalorados", alardeava a Gazeta de Notícias de 22 de dezembro. A sessão atraiu vários oradores. Calógeras votou contra, Irineu Machado, a favor, Correia de Freitas considerou o retorno da família imperial "um perigo para a República". Opinião mais do que esperada, Maurício de Lacerda apoiou a revogação do banimento, por julgar que nenhum sistema republicano verdadeiramente democrático podia deixar de reconhecer a oposição monárquica, que segundo ele não oferecia qualquer ameaça às instituições.

As discordâncias se aprofundam. Em artigo publicado pelo jornal $A$ Imprensa desse mesmo dia Alcindo Guanabara enaltece "o ato de bom senso" com que a Câmara recusou a revogação do banimento da família imperial. "Seria rematada loucura dar entrada no país ao príncipe que se julga com direito ao trono e que entende de pleitear por esse direito, como está fazendo, aliás, com tanto êxito, que obtém que venha ser arauto de sua pretensão um ministro diplomático da República, diante do qual - ele assinala não sei por quê o governo se desfaz em zumbaias, quando o deveria reconhecer incompatível com ela para continuar no exercício dessas funções”.

No centro da polêmica, D. Luiz é alvo de vários depoimentos de estudantes de Direito em reportagem publicada pela Gazeta de Notícias no dia 23 de dezembro. "Duvido que se possa restaurar a monarquia... não acredito na sua sinceridade... ele ameaça-nos com o domínio católico e militar", afirma um tal Ribas Carneiro. "Sou republicano, mas reconheço que no Brasil a República está prostituída... a permanência de Pinheiro Machado à frente do regime é que nos tem desgraçado, tornando talvez possível a restauração monárquica" (Augusto Sabóia). "O que precisa se restaurar aqui é a República" (Salles Pinto Jr.). "Se tivéssemos um Bonaparte, a monarquia seria uma salvação para o Brasil” (Ribeiro de Carvalho). "Uma restauração monárquica traria, com D. Luiz, o rosário e o militarismo" (Renato Vilela). "Acho a monarquia superior à Republica. A tendência social não é para outro regime senão o dos monarcas" (Pedro Paranaguá). Os anarquistas também se manifestam. Curvelo de Mendonça, no artigo "Príncipes e povos", publicado essa mesma manhã no jornal O País, aplaude o recente repúdio da Câmara, que 
com maioria insofismável (80 contra 36 votos) "esmagou serenamente a cabeça da hidra" imperial, através de um gesto a seu ver "de patriotismo, de sinceridade e de firmeza".

O assunto já escapava aos limites do Rio de Janeiro. Em São Paulo, A Platéia de 23 de dezembro de 1912 trazia uma conferência de Rangel Moreira aos estudantes do Mackenzie College, exaltando o legado de Pedro II com inúmeras citações de João Ribeiro, Silvio Romero, Campos Sales, Montesquieu, Caxias, Araújo Jorge e, particularmente, de Oliveira Lima, que aliás agradeceria ao autor pela justeza das teses expostas em sua fala. ${ }^{6}$ De fato, inspirado no livro Formation historique de la nationalité brésilienne, de Oliveira Lima, Rangel Moreira reafirmava aos jovens de São Paulo que o Imperador Pedro II fora "o mais nobre dos homens e o mais completo dos soberanos", razão pela qual os exortava a repudiar "a influência corruptora dos Nilos e dos Hermes", repisando essa "época de deserções, de indignidade, de desonra política, em pleno regime de degradação moral" que identificava particularmente na figura de Pinheiro Machado, segundo ele um "misto de poltronaria, de astúcia e de cinismo". Que os jovens de São Paulo fossem pedir ao passado "a lição dos bons exemplos para que os nossos espíritos se não deixem vencer pelo flagelo que anda a debilitar o caráter de nossos compatriotas".

Já de Minas vinham sérias restrições aos propósitos de Oliveira Lima. Em artigo para o Diário do Povo de Juiz de Fora, naquela mesma semana, o velho republicano J. Nogueira Itagiba dava outra versão para as reais intenções do ex-ministro, que segundo ele, depois de tirar vantagem das faculdades e regalias que a diplomacia proporcionava, "e enfastiado das honras proveitosas que os nossos governos lhe conferiram, descobriu que só o regime monárquico convém ao Brasil e vem converter-se em apóstolo da nova religião". Na verdade - argumenta - estava é de olho numa cadeira no Senado ou na Câmara, "à ilharga de Carlos de Laet, do conde de Afonso Celso e de Martim Francisco". Que todos eles venham a público - ele emenda - para assumir um partido rijo e sem qualquer embuste, e assim “combater os erros da República”. O que não se pode - dirige-se então a Oliveira Lima - é conspirar contra a ordem "ocupando funções rendosas no seio da República, para traí-la com as próprias armas que ela confia para a defesa da nação e do regime".

A zanga do velho republicano vem num momento em que ainda estavam no ar os ecos de uma sátira recente publicada n'O País do dia 21 contra o príncipe D. Luiz de Bragança, chamado no texto de "D. Lulu I futuro". Sustentando ter sido um erro a rejeição do projeto de Maurício de Lacerda, que revogava o banimento da família real, a nota lamenta que com isso o Brasil perdia a oportunidade de conhecer "a estatística exata dos monarquistas brasileiros... indo por água abaixo o ídolo com todas as suas condecorações". Além do que - emendava a notícia - "sua Alteza é de uma antipatia invencível", que aumentava a cada tentativa que ele fazia de ganhar popularidade, fosse "passeando a pé pela Avenida, (fosse) inscrevendo-se nos clubes de regatas".

Dois medalhões do antigo regime saem em defesa do príncipe D. Luiz e de Oliveira Lima no dia 25 de dezembro de 1912. Na coluna "Microcosmo" de O País, Carlos de Laet, a pretexto de analisar a recusa pela Câmara do projeto que estabelecia o fim do exílio da família real, que a seu ver só veio confirmar os direitos dinásticos dos descendentes do Imperador, insiste em contrapor a dignidade do Império à inconsistência moral do parlamento. Depois de lembrar que Pedro II recusara o benefício da pensão vitalícia 
por não admitir que os republicanos "sacassem do Tesouro do povo o dinheiro que lhe garantiria a velhice”, o áspero polemista sustenta que pela Constituição republicana o banimento, como as galés, estava abolido, já que nenhuma pena podia ir além da pessoa do imputado. Além do mais, - ele conclui - "o reinado de Pedro II já está julgado pelo povo, que o teve sempre como grande soberano, e a $\mathrm{D}$. Isabel como a redentora dos escravos".

O "ilustre conselheiro Silva Costa, membro do antigo Conselho de S.M. o Imperador", em depoimento à Gaz̧eta de Notícias, interpreta a restauração como uma aspiração legítima de todos quantos se interessavam pela "venturosa prosperidade do Brasil". Diz isso - segundo explica - por estar convencido de que à frente do movimento estavam dois patriotas irrepreensíveis. De um lado, o ex-ministro Oliveira Lima, que o impressionava não apenas "pela elevada intuição do espírito superior", mas sobretudo porque sua campanha vinha "coincidir com o meu inquebrantável sentimento de monarquista, sem desfalecimentos e sem ódios”. E, de outro, o príncipe D. Luiz de Orléans e Bragança segundo Silva Costa "um perfeito conhecedor dos grandes problemas econômicos e políticos que se agitavam no Brasil" - que lhe inspirava a certeza de que a propaganda monárquica era um dever não só dos monarquistas, mas de todos "os republicanos desiludidos e de boa-fé".

Nem bem se assentavam essas palavras de ordem e, no dia seguinte, Nogueira Itagiba reaparecia nas páginas do Diário do Povo de Juiz de Fora para retomar os ataques aos dois paladinos do antigo regime. Oliveira Lima não lhe merecia qualquer confiança: cansado de "alisar os salões europeus" em busca do sonho dourado da Legação de Paris, o que o ex- ministro buscava - a seu ver - era um atalho para ocupar o lugar de Olinto Magalhães como ministro plenipotenciário na capital francesa. Mas "a inveja matou Caim e vem imolar o sr. Oliveira Lima na linda carreira percorrida", ele arremata. Sobre D. Luiz, as restrições eram ainda mais graves, dado que Sua Alteza - a crer no articulista "desconhecia vergonhosamente a história do Brasil" e talvez mesmo a sua posição geográfica, o que bem explicava - segundo Itagiba - que a sua cruzada política coubesse inteira "nas malas do embaixador Oliveira Lima".

Não demora e a crítica reverte em chacota. Dois dias depois, a 28 de dezembro de 1912, sai na revista Careta, assinado por Jean Grimace, o seguinte "Epitáfio diplomático" de Oliveira Lima:

Farto de haver da vida contemplado

As comédias e os dramas,

Aqui jaz um varão avantajado,

Do peso de uns duzentos quilogramas.

Ministro brasileiro,

Entendeu que a missão dos diplomatas

Não era apenas esbanjar dinheiro

$E$ variar de gravatas.

Atingir a velhice não logrou:

Tendo-lhe visto o monarquismo forte,

Satanás o levou

Para lugar conspicuo em sua Corte" 
E n'O Imparcial de 30 de dezembro vem uma caçoada sobre "As profecias para 1913", assinada pelo hierofante Múcio Teixeira. A galhofa, que misturava "por entre a névoa teosófica as aparições de Hermes Trimegisto, as figuras de Baader, Jacques Boehme, Weigel e Swedemborg ... numa linguagem estranha, inçada de palavras exóticas e de formulas cabalísticas", traz a seguinte previsão do barão Ergonte: “ - Vejo, num dia ímpar, de mês ímpar, do ano ímpar de 1913 - a restauração da monarquia no Brasil, com o príncipe D. Luiz de Bragança coroado Imperador", ao lado de um novo Bonaparte, simultaneamente coroado na França.

Desgastado com a virulência da troça, que tendia a expandir-se, indispondo-o cada vez mais com o Itamaraty e o Governo, Oliveira Lima decide afastar-se da cena política e retomar o curso de sua carreira diplomática. Um informe de $A$ Noite de $1^{\circ}$. de janeiro de 1913 dava como definitivo o seu empenho em não se aposentar e continuar postulando a nomeação para a embaixada de Londres, para onde mostrava desejo de se transferir, apesar de "O sr. Lauro Muller - nos termos da nota - querer confiar-lhe o posto em Buenos Aires".

O ideal da restauração não parecia mesmo ter grande futuro. Apesar de o povo estar visivelmente descontente, segundo palavras de Rui Barbosa estampadas n'A Notícia do dia 13 de janeiro, nada indicava que Oliveira Lima e os monarquistas tivessem êxito em sua campanha de propaganda em favor do antigo regime. Rui concordava com o rude Lopes Trovão em que o maior inimigo da República eram os próprios republicanos, responsáveis diretos pelos erros governamentais oferecidos à oposição. Trovão, no entanto, é mais cáustico do que Rui. "Que príncipe é esse?” - perguntava ele n’ A Notícia do dia 11: "um desconhecido cuja capacidade nos escapa, mesmo no livro a que deu publicidade". "E, depois, - adverte - com que homens pretende ele governar? Com os estadistas que nos legou o Império? Ouro Preto, Andrade Figueira, João Mendes, Couto de Magalhães, Paranaguá, Sinimbu, Joaquim Nabuco, João Alfredo, Afonso Celso, Martim Francisco" gente em sua maioria morta ou valetudinária? "A melhor resposta que lhes podemos dar" - ele, Trovão, e outros republicanos como Coelho Lisboa, Avelar Brandão e Pedro do Couto - é a convicção de que “já estamos apalavrados para dar-lhes combate” com a certeza de que a República "já deu uma prova da sua superioridade sobre a monarquia, debelando a pústula que está aí a exigir cautério".

"Se a República não é a dos sonhos dos antigos propagandistas, escreve Vitor Viana ao Jornal do Comércio do dia 14, a monarquia de Pedro II não é a dos sonhos de seu ilustre neto", mais afeito - segundo o autor de O código de Weimar e a moderna Alemanha - à "monarquia prussiana, que pouco difere, afinal, da atual monarquia russa, que tem uma Duma e um Senado. O príncipe - segundo Viana - quer um soberano que governe com ministros só responsáveis perante ele próprio; quer câmaras que votem as leis como as nossas câmaras do regime presidencial, sujeitas a vetos e só intervindo na administração pela votação das leis e dos meios; quer preferência para o clero", o que pouco mudaria as instituições em vigência. E deixa então uma pergunta: "uma monarquia assim não seria a entrega de toda a máquina do Governo ... a um só homem, e para sempre?"7

Mais articulados, os republicanos davam claros sinais de querer acuar o inimigo. No dia seguinte, Francisco Glicério retorna às páginas de $O$ País para alertar os republica- 
nos sobre os perigos da conspiração monarquista, contra a qual - dizia ele - só "uma coligação entre os homens de boa-fé devotados sinceramente ao regime republicano" seria capaz de produzir a reação que toda a nação esperava. Alarmado diante dos fatos que se agravavam a cada dia, ele acredita que só "pela prudência, pelo espírito de paz, pelo sentimento direto, pela observância das aspirações populares é que se há de inutilizar a idéia restauradora, se ela descer da região da fantasia ao campo da luta audaz".

O Exército, entrementes, se entrincheirava para repelir os conspiradores. Em nota publicada nesse mesmo jornal em 17 de janeiro de 1913, lemos que "o sr. ministro da Guerra subiu a Petrópolis para despachar com o marechal Hermes", reorganizar o antigo Batalhão Patriótico - de tão grata memória pelos relevantes serviços prestados ao marechal Floriano durante a Revolta da Armada, - e, em ato contínuo, restaurar as antigas Linhas de Tiro. A medida se justificava principalmente diante dos boatos que circulavam pelo Rio de Janeiro dando conta de que eram muitos os republicanos históricos convertidos à restauração.

De fato, o Batalhão Tiradentes reuniu-se às 14 horas do dia 19 de janeiro de 1913 em ato convocado pelo comandante Alfredo Vicente Martins para - segundo informa $O$ País em sua edição do dia 20 - "dar conhecimento oficial de ato do governo que restaurou aquele corpo patriótico, dissolvido pelo governo do presidente Prudente de Morais, em 1897". Depois de aludir aos rumores de conspiração contra o regime, "que corriam alhures", o coronel garantiu que, em caso de qualquer ameaça às instituições, o Batalhão estará mais uma vez "no seu posto de honra". A nota acrescenta que "todos os presentes, entre calorosos aplausos, declararam-se prontos a tomar o seu lugar à sombra da velha e gloriosa bandeira". O coronel Alfredo Martins deu então por finda a reunião, "levantando um viva à República, entusiasticamente correspondido". Em seguida "foram levantados vivas ao batalhão Tiradentes e à memória do marechal Floriano".

À medida que os ânimos se acirravam na esfera militar, Oliveira Lima - absorvido pelo impasse das decisões na área diplomática - afastava-se do príncipe D. Luiz, agora exposto a um fogo cada vez mais intenso. Este, para neutralizar os ataques que vinham de todos os lados, passa a concentrar o foco de sua cruzada na redenção das forças armadas, às quais prometia reservar um papel decisivo na plataforma do futuro governo monarquista.

A estratégia parecia dar bons resultados, pois eram cada vez mais freqüentes as notícias de que velhos militares antes fiéis ao credo republicano passavam-se agora para o lado dos monarquistas, como o capitão Júlio do Carmo, antes um dos mais ardorosos republicanos do Império e agora um soldado desiludido com os rumos do Governo, que - segundo ele - não cumpriu o programa de 1870 e nem tampouco transformon em realidade "O que foi prometido por Saldanha Marinho, Aristides Lobo, José Maria do Amaral, Rangel Pestana, Quintino Bocaiúva e tantos outros que se foram para o além ralados de desgostos".

Ouvido pela reportagem da Gazeta de Notícias, o príncipe D. Luiz afirma no dia 18 de janeiro que "o desgosto e a malversação das instituições atuais geram explosões como as do ilustre militar" a que acabamos de nos referir. A declaração aparece numa nota onde se diz que Sua Alteza, depois de haver jurado à bandeira, manifestou-se publicamente em desacordo com a forma pela qual a República tem explorado os nossos soldados. 
"Faz-se do Exército e da Marinha - ele declara - uma espécie de espantalho eleitoral e político, desvirtuando-se a nobilíssima e elevada missão que lhes toca na vida nacional".

"D. Luiz promete um exército de 100 mil homens" é a manchete do jornal A Hora do dia 23 de janeiro de 1913, em página cheia de alusões aos "monarquistas do Exército e da Marinha", à "propaganda nos jornais", às “opiniões nos quartéis e nas ruas", à "nova geração" e aos "tenentes de 89 e os de 1913”. Informava-se que a restauração monárquica seguia conquistando novos adeptos por todo o Brasil, principalmente nas capitais dos estados, onde se infiltrava nas fileiras do Exército e da Marinha. A ressurreição do Batalhão Tirandentes "não podia ser uma simples pilhéria do sr. Vespasiano", como não era normal que o chanceler Lauro Muller, "republicano e tenente de 89", "acenasse com as gordas vantagens de uma aposentadoria republicana" ao ex-ministro Oliveira Lima. Tudo indicava que o avanço dos conspiradores já não respeitava fronteiras. "O Exército é republicano e morrerá pela República”, garantia exaltado o coronel Joaquim Inácio, enquanto o primeiro-tenente Mário Clementino advertia que, se o povo quiser e as forças armadas apoiarem, a viabilidade da monarquia "será facílima".

Diante desse alvoroço nos quartéis, $A$ Época de 24 de janeiro já fala em "ditadura militar mais ou menos munida de espora e rebenque" para garantir "a subida de Pinheiro Machado - adversário político de Oliveira Lima - à Presidência da República. "Dentro em breve serão chamados o Batalhão Frei Caneca e logo depois o Batalhão Silva Teles", que juntamente com o Batalhão Tiradentes se encarregarão desse ato de força que o jornal considera ultrajante.

Inteirado dos fatos, o general de divisão Marques Porto, chefe do departamento da Guerra, declara ao jornal $A$ Hora do dia 25 que D. Pedro II injuriou uma vez os soldados do Exército, aos quais não perdoava a deposição de seu pai em 1831. "Assistia o Imperador à passagem, em desfilar, de uma divisão do Exército - ele conta - quando, voltandose para um seu íntimo, disse: - Assassinos legais?". E o general acrescenta: "Se o grande Pedro II assim pensava, que faziam os demais apaniguados do trono?”.

Três dias depois, dois outros generais, Caetano de Faria e Souza Aguiar, voltam às páginas do mesmo jornal para negar de público qualquer tendência monárquica entre os oficiais do Exército. Nesse mesmo dia 28 de janeiro sai n'O Imparcial uma entrevista com o filho do marechal Floriano Peixoto, dr. Artur Peixoto, que expõe longamente ao repórter a honestidade do pai e a frugalidade da vida que levava. Segundo Artur, o Marechal "saiu do governo com os mesmos bens de que dispunha quando entrou, acrescidos de uma casa situada à rua Visconde do Rio Branco, no. 2, antigo; um terreno em Copacabana, comprado em prestações; 300 ações da Cooperativa Militar do Brasil (única sociedade de que foi acionista) e cento e poucas apólices compradas por mim, de $5 \mathrm{em}$ 5 , mensalmente". Diz ainda que suas filhas, - bem como a viúva de Floriano, que com o passar do tempo foi se vendo em dificuldades em razão da generosidade excessiva do marechal ("à sua mesa sentavam-se diariamente cerca de 30 pessoas"), - não fora a pensão de 200 mil réis mensais, "estariam em dificuldades na vida". Dos oito filhos do Marechal, diz Artur que "nunca tiveram colocação, nunca se aproveitaram da posição de Floriano". 
A essa altura chegavam de São Paulo notícias desencontradas sobre o destino diplomático de Oliveira Lima. O Estado de S. Paulo de 27 de janeiro, diante da disposição de Domício da Gama em permanecer na embaixada de Washington a qualquer preço, sai em defesa do ex-ministro, ao tornar pública a posição do chanceler Lauro Muller, que segundo a folha paulista - entendia, "com muita razão que não se explicava a conservação do sr. Domício da Gama no posto culminante da nossa representação diplomática no estrangeiro, quando nós temos, afastado de uma comissão condigna, um homem da estatura intelectual do sr. Oliveira Lima". E chega a aventar uma solução para o impasse: Oliveira Lima seria enviado provisoriamente a Buenos Aires, indo depois em caráter definitivo para Washington na direção da embaixada do Brasil.

Mas essa não era a verdade dos fatos. Em 2 de fevereiro de 1913 circula no Rio um informe da Gazeta de Notícias segundo o qual o novo ministro do Brasil em Buenos Aires não havia ainda sido escolhido, sendo certo entretanto que não seria o sr. Oliveira Lima, a essa altura já informado de que lhe concederiam a aposentadoria. A notícia chega a São Paulo no mesmo dia pelo Estado, cuja nota procura atenuar o impacto da decisão contrária a Oliveira Lima, ao informar que o ex-ministro ainda disputava o cargo de Londres, "que sempre foi um dos postos em que desejou colocá-lo o ministro das Relações Exteriores”. A nota reconhece algumas dificuldades, mas não diz quais. Refere apenas que um "amigo fiel e homem de grande prestígio social no nosso meio, o sr. Regis de Oliveira," vem trabalhando para convencer o ex-ministro de que "a melhor providência que lhe cabe tomar é aposentar-se".

$\mathrm{Na}$ área militar o movimento permanecia intenso. O Correio da Manhã de 3 de fevereiro destaca as preocupações do general Feliciano de Morais com as atuais condições do Exército brasileiro, "desgraçadamente tocado pelo vírus da politicagem" num momento em que, à exceção da capital da República, todas as regiões militares sobreviviam na precariedade. "Batalhões e regimentos incompletos com os seus oficiais flanando pelo Rio de Janeiro, artilharia sem bocas de fogo, sem animais de tração, sem arreamento, sem educação e instrução; cavalaria sem cavalos, sem barracas, carretos de bagagem, munições e ferramentas" - tudo isso contribuía para expor a fragilidade da caserna diante de um ataque que poderia ser iminente.

No dia 5, sai n' $A$ Notícia uma nota sobre a reorganização do antigo Batalhão Acadêmico, criado por Benjamim Constant no Governo Provisório, que lutou bravamente na Revolta da Armada, aquartelando-se primeiro no Arsenal de Guerra e depois no Morro do Castelo. "Não se deve desprezar o inimigo por julgá-lo fraco", afirmou o general Caetano de Faria ao passar a presidência do Clube Militar ao seu colega Tito Escobar no dia anterior. Nesse momento em que "a idéia da restauração monárquica procura insinuar-se nos espíritos, explorando paixões, interesses contrariados, erros cometidos e inevitáveis" - o velho cabo de guerra fez questão de transformar a sua despedida numa severa advertência: "se a onda se avolumar, o Clube Militar tem o dever, por suas tradições e por sua responsabilidade histórica, de constituir o mais forte reduto da Fé Republicana" - declarou sob os aplausos entusiásticos da soldadesca.

Nos dias que se seguiram os jornais estranharam que o presidente empossado do Clube Militar, general Tito Escobar, não retomasse, em seu discurso, a mesma defesa enérgica do regime republicano feita pelo seu antecessor e que sequer se referisse a ela. 
O jornal A Hora de 7 de fevereiro de 1913 interroga o porquê desse silêncio e a Gazeta de Notícias do dia 12 publica carta de um distinto oficial desmascarando a farsa montada pela imprensa monarquista, segundo a qual o general Tito era um adepto da restauração e por isso nada teria dito que reforçasse a profissão de fé republicana manifestada pelo general Caetano de Faria. Ao contrário, para o ilustre missivista a monarquia era o verdadeiro pretexto para o general Vespasiano organizar no Rio de Janeiro uma guarnição capaz de servir aos interesses políticos do senador Pinheiro Machado.

Os ânimos castrenses pareciam agravar-se diante da iminência do suposto levante comandado por D. Luiz de Orléans e Bragança, a essa altura cada vez mais isolado na trincheira da restauração. Desde o dia 7 de fevereiro, quando $O$ Imparcial publicou as declarações do marechal Bormann, revelando que os oficiais do Exército que voltavam da Alemanha vinham "imbuídos de idéias imperialistas e francamente adeptos do regime monárquico", a tensão parecia insuportável. Muitos oficiais, julgando-se atingidos pela notícia, vão pedir providências ao ministro da Guerra contra os excessos de franqueza do marechal Bormann para com os jornalistas. Aludia-se abertamente aos jovens turcos do Exército e da Marinha como representantes da vanguarda mais atuante do adesismo militar à causa da restauração monárquica. "O sr. Rosa e Silva aderiu à causa restauradora?" - pergunta a Gazeta de Notícias de 8 de fevereiro, informando que "s.exa. mandou que os seus amigos de Pernambuco conclamassem as péssimas condições do país na vigência do atual regime e acrescentasse que a vinda de D. Luiz não deveria insurgir a Nação contra as suas pretensões ao trono".

Tudo isso culmina com uma entrevista do major Augusto de Sá, ex-professor da Escola Militar de Porto Alegre, publicada nesse mesmo jornal no dia 13 de fevereiro de 1913. Nela o major desafiava a seus companheiros antimonarquistas do Exército a negarem "a importantíssima influência, inclusive consangüínea, do Kaiser no exército alemão", um governante a quem dizia respeitar como o autêntico liame do chefe sobre a tropa - um elo que, a seu ver, podia se repetir entre nós agora que D. Luiz - segundo o ele - reunia todas as condições de "assumir o seu ofício de imperador do Brasil", ele que escapou ao maneirismo do avô letrado e filósofo e, filho de um grande soldado (o conde d'Eu), teve a sua educação "especialmente dirigida para a profissão da sua raça: governar povo e exército".

A D. Luiz e seus partidários só restava, de fato, insistir na aproximação com as forças armadas, vistas por eles como uma reserva moral do futuro governo monárquico. Isso explica que o jornal $O$ País de 10 de fevereiro desse em destaque que um dos fundamentos do manifesto-programa divulgado pelo príncipe há algumas semanas fosse justamente o do fortalecimento do poder militar, que "a incapacidade dos governos republicanos tem deixado num plano inferior ao de outras nações americanas".

Atingida em seus brios, a caserna reage. Dois dias depois, sai estampada n' $A$ Notícia, com o título "O Exército na República", uma matéria interessada em mostrar aos leitores que o próprio d. Pedro II morrera convencido de que a República era irreversível no Brasil. $\mathrm{O}$ argumento do texto era de que o Exército e o povo jamais haviam traído o Imperador: ao contrário, teria sido este que se conformara com as idéias "que avançavam e com as quais ele, do mesmo modo que hoje o seu augusto neto, podia dizer que não 
tinha o direito de se harmonizar nem de manter uma coroa que não era mais possível sem se afundar ainda mais num abismo que já estava muito fundo".

Novos e acirrados confrontos viriam ainda nos meses que se aproximavam. Do destino de Oliveira Lima, entretanto - àquela altura definitivamente afastado das operações de combate - as notícias eram cada vez mais contraditórias. A Notícia de 11 de fevereiro voltou a informar a disposição do ministro Lauro Muller - antes de seguir em missão especial à América do Norte - em "fazer grandes remodelações nos serviços de sua pasta", incluindo entre elas a de fazer de Oliveira Lima "representante do Brasil junto de sua Majestade britânica". O próprio Oliveira Lima, falando informalmente à redação do jornal, em atitude que nada lembrava o antigo conspirador, mostrava-se "disposto a aceitar qualquer cargo que lhe fosse indicado pelo governo da República, desde que daí não lhe pudessem resultar agravos para o estado precário de sua saúde". Dois dias depois, o que se configurava como um desfecho feliz, parecia confirmar-se. Em São Paulo o Estado dava a nomeação como fato consumado, ao informar que havia sido "acolhida com satisfação por ser o novo ministro um espírito culto, um historiador consciencioso e um cavalheiro distinto", já conhecido em Londres, onde fora secretário de Legação. E $A$ Notícia desse mesmo dia 13 de fevereiro confirmava os fatos, sublinhando que "a nomeação do dr. Oliveira Lima para o cargo de ministro do Brasil na Inglaterra causou ótima impressão em todas as rodas diplomáticas", com destaque inclusive no Financial Times, onde a indicação teria sido "recebida com aplausos de todos os círculos financeiros".

Os ventos pareciam soprar a favor de Oliveira Lima. No dia seguinte O Imparcial, em matéria assinada, informa que mal se noticiou a nomeação do ex-ministro para o posto de embaixador do Brasil em Londres, "começou contra ele uma pequena e insidiosa campanha, com o manifesto fim de demover o Governo dessa nomeação”, por ser o ministro - explicava a nota - monarquista e inimigo do barão do Rio Branco, recentemente falecido. Mesmo reconhecendo que foram adversários, o artigo não vê em Oliveira Lima um monarquista, ao contrário: "Desde moço - lemos no texto - foi republicano e toda a sua vasta obra é uma declaração de republicanismo, embora de um republicanismo inteligente, esclarecido e civilizado, e não do republicanismo anacrônico e bronco dos clubes, dos batalhões patrióticos e dos exploradores da República". Em favor de Oliveira Lima e de sua postulação, o artigo destacava a sua nobreza de espírito, ao lembrar que, mesmo sem ser amigo de Rio Branco, publicou por ocasião de sua morte um artigo de dez páginas na Revue de l'Amérique em que o apontava como "uma das personalidades mais notáveis não só do seu país como das duas Américas".

A Noite de 21 de fevereiro noticiava a presença de Oliveira Lima primeiro em São Paulo e depois em Pernambuco. Em São Paulo, onde já se previa a sua recepção como "embaixador em Londres" para a primeira quinzena de maio, o ex-ministro seria homenageado por amigos e admiradores. Seguiria depois para Pernambuco em visita a parentes de sua esposa. De Pernambuco - em nota também confirmada pela Gareta de Notícias finalmente seguiria para Londres, "a fim de assumir o seu posto diplomático".

Foi este o último despacho auspicioso a dourar na imprensa o sonho europeu da carreira diplomática de Oliveira Lima. Poucos dias depois, a 28 de fevereiro, o Correio da Manhã se encarregaria de trazer as coisas para a realidade concreta que as articulava. 
"Errada e condenável a escolha de Oliveira Lima para Londres", assim abria a nota que devolvia a questão para o conhecido argumento da coerência pessoal e a honestidade dos princípios. "Se Oliveira Lima fosse o gentleman e homem culto que dizem ser - sustenta o jornal - não aceitaria o cargo por uma simples condição de atitude ética: não pode servir à República e dela beneficiar-se num alto cargo quem se declarou monarquista militante".

No contexto das forças dominantes, já se articulava a campanha civilista com Rui Barbosa candidato à sucessão do marechal Hermes da Fonseca. "O civilismo vai voltar a campo e agirá com eficácia", declarou o "Águia de Haia” ao jornal Gaz̧eta de Notícias, que o recomendava aos leitores convencido de que "o espírito sempre luminoso" de Rui marcharia com o povo para a vanguarda das nações civilizadas em que a soberania emanava dos cidadãos comuns. O próprio Rui Barbosa falando a'O Imparcial de 7 de março de 1913 afirmava o compromisso de fazer conservar as antigas tradições brasileiras do tempo do padre Feijó, "quando as nossas instituições militares, mais modestas e menos vorazes, asseguravam ao Império o respeito dos nossos vizinhos e uma auréola de consideração geral".

A tese da restauração monárquica ia assim perdendo fôlego ante o consenso, que aos poucos se firmava, de que era possível preservar a República livrando-a dos excessos do poder militar. Perdido em meio ao noticiário que ia gradualmente amortecendo os ímpetos da fé monarquista, D. Luiz - abandonado na trincheira - vez que outra reaparecia nos jornais, mas já sem trazer consigo a imagem temerária de conspirador incansável. Falavase dele, em notas esparsas, como de algo distante e já diluído pela crônica da história recente - uma reunião do Centro Beneficente da Guerra do Paraguai para homenagear a memória do Conde d'Eu na comemoração dos quarenta e três "da terminação do sangrento combate" (Jornal do Comércio, 2 de março de 1913); um informe sobre o Centro Monarquista de São Paulo, encarregado de distribuir o Manual do monarquista aos adeptos do regime deposto ( $A$ Noite, de 6 de março); ou a alusão a uma cruzada cívica em que Sua Alteza aparecia querendo "civilizar o sertão", eliminando o analfabetismo, reorganizando as finanças e terminando com os currais eleitorais (Jornal do Comércio de 27 de agosto).

A essa altura a carreira diplomática de Oliveira Lima já estava selada nas mãos de seus detratores. Em 5 de março de 1913 um artigo de Edmundo Bittencourt no Correio da Manhã praticamente exige do governo que não confirme a sua nomeação para Londres. "O que nos dói não é ver o marechal Hermes assinar a nomeação do sr. Oliveira Lima e dar-lhe uma carta apresentando-o, como representante de sua confiança, ao soberano da nobre e austera Inglaterra [...]. O que nos dói é ver o sr. Oliveira Lima baixar-se à altura do sr. Hermes, depois de, merecidamente, ter subido tanto no conceito do público" circunstância que justificava, segundo o jornal, que perdesse "o direito a exercer um cargo de excepcional confiança e distinção na República”.

Os fatos demonstraram que efetivamente o perderia. Na manhã de 11 de março o mesmo Correio da Manhã informava que, reunido no palácio de Petrópolis com Pinheiro Machado e outros políticos de seu grupo, o marechal Hermes decide queimar definitivamente a indicação de Oliveira Lima. "Hermes começou a falar da nomeação de Oliveira Lima para ministro do Brasil em Londres - relata o jornal - e logo foi dizendo que, 
absolutamente, ela não se podia realizar. Volta-se depois para o gaúcho e diz, sério: - Sr. Pinheiro, eu não sei se já assinei o decreto; mas, se tiver assinado, mande o Senado pôr abaixo".

Acabava aí o sonho de Londres e o curso da aventura monarquista do autor do $D$. João VI no Brasil. Em 27 de agosto de 1913 é aposentado como diplomata e pouco depois regressa à Bélgica para as despedidas de praxe. Em 22 de abril de 1914, é homenageado num banquete no Hotel Astória em Bruxelas, ocasião em que falaram Victor Orban, Alphonse de Busshere e Paul Otlet, entre outros, segundo informou o L'Independence belge. Nos quatro ou cinco anos que se seguiram, andou lecionando nos Estados Unidos, visitou a Argentina, onde colaborou na imprensa e fez conferências, e esteve no sítio da família em Parnamirim, ocasião em que participou das comemorações do centenário, em 1917, da revolução pernambucana. Pouco depois, seguiria para Washington, para trabalhar como professor da Universidade Católica da América, à qual havia doado o impressionante acervo de livros, documentos e obras de arte reunidos ao longo de sua vida. De lá não retornaria mais ao país e lá, por manifestação de própria vontade, fez questão de ser sepultado. ${ }^{8}$

\section{Notas}

1 Nesse escrito, refere-se à "personalidade simpática de D. Luiz", que ele então considerava um "príncipe sem pretensões e entretanto dotado de nobreza, que as distrações da Europa, as grandes viagens não fizeram olvidar, menos ainda desprezar, o país maravilhoso que seu bisavô proclamou livre, que seu avô amou como nenhum outro brasileiro o amou melhor, pelo qual seu pai expôs a vida nos campos de batalha e que serviu na paz com dignidade e zelo incomparáveis e que sua mãe alforriou de uma infâmia secular". Cf. O Estado de S. Paulo, 9 set. 1910.

2 Sigo no tópico as indicações de Teresa Malatian em seu belo estudo Oliveira Lima e a construção da nacionalidade. São Paulo: Fapesp; Bauru: EDUSC (2001), p. 199 ss.

3 Pouco antes, um incidente em Bruxelas agravara o estado de suas relações com o governo. É que Oliveira Lima se recusou, como representante do Brasil, a ir assistir ao desembarque de Hermes da Fonseca, recém eleito presidente da República, então em visita à Bélgica. A partir daí, passou a receber ataques sucessivos da imprensa republicana por essa omissão protocolar, "considerada pelos hermistas uma afronta ao marechal". Cf. Teresa Malatian, op. cit., p. 238.

4 É verdade que, em carta dirigida a Lauro Muller em 6 de março de 1913, Oliveira Lima fez questão de deixar ao inteiro arbítrio do ministro das relações exteriores a resolução do seu caso, para que assim, conforme escreve, "não julgue V.exa. comprometido comigo pela sua bondade, que tanto menos esquecerei quanto a considerei um ato de justiça e de reparação pelo meu anterior afastamento do serviço mais ativo e mais importante da casa a que V.Exa. felizmente preside, e a que nestas condições tanto gosto tenho em pertencer". Cf. Oliveira Lima. Memórias - estas minhas reminiscências. Rio de Janeiro: José Olympio (1937), p. 255.

5 Referência ao volume Sous la Croix-du-Sud: Brésil-Argentine, Chili-Bolivie-Paraguay-Uruguay. Paris: Plon (1912).

6 Em carta enviada ao autor em 13 de janeiro de 1913, Oliveira Lima de fato agradece a Rangel Moreira os elogios de que foi alvo, em particular - como acentua - pelo acerto das teses expostas sobre o significado e o papel de D.Pedro II enquanto esteio do regime imperial. Cf. acervo da Biblioteca Oliveira Lima na Universidade Católica da América em Washington.

7 A propósito das inovações políticas do príncipe D. Luiz de Orléans e Bragança, cabe mencionar que Martim Francisco considerava o seu manifesto modernizante um verdadeiro projeto de "monarquia republicana", causando sérias dissensões no seio do diretório monarquista, com a retirada inclusive de Andrade Figueira. Com essa nova plataforma. "D. Luiz feria o diretório, que além de se sentir desprestigiado, não poderia admitir 
que o soberano abandonasse a posição do Poder Moderador: a eqüidistância dos partidos... Mesmo assim, o diretório conviveu com as impertinências de D. Luiz", escreve Maria de Lourdes Mônaco Janotti em Os subversivos da República. São Paulo: Brasiliense (1986), pp. 255-256.

8 Este estudo faz parte de um projeto mais amplo sobre a obra crítica de Manuel de Oliveira Lima, desenvolvido em 2002 junto ao acervo da biblioteca do Autor depositada na Universidade Católica da América, em Washington, para o qual contei com o valioso apoio da John Simon Guggenheim Memorial Foundation, à qual deixo aqui registrados os meus melhores agradecimentos. 